\title{
Household income and risk-of-poverty of parents of long-term childhood cancer survivors
}

Luzius Mader $(\mathrm{MSc})^{1}$, Katharina Roser $(\mathrm{PhD})^{1}$, Julia Baenziger $(\mathrm{MSc})^{1}$, Eva Maria Tinner $(\mathrm{MD})^{2}$, Katrin Scheinemann (MD) ${ }^{3}$, Claudia Elisabeth Kuehni (MD; MSc) ${ }^{4}$, Gisela Michel (PhD) ${ }^{1,4}$; For the Swiss Paediatric Oncology Group (SPOG)*

${ }^{1}$ Department of Health Sciences and Health Policy, University of Lucerne, Frohburgstrasse 3, 6002 Lucerne, Switzerland;

${ }^{2}$ Pediatric Hematology/Oncology, Department of Paediatrics, University of Bern, Bern, Switzerland;

${ }^{3}$ Division of Hematology/ Oncology, University Children's Hospital Basel (UKBB), University of Basel, 4056 Basel, Switzerland; and Division of Hematology/ Oncology, McMaster Children's Hospital \& McMaster University, Hamilton ON Canada;

${ }^{4}$ Institute of Social and Preventive Medicine, University of Bern, Finkenhubelweg 11, 3012 Bern, Switzerland.

*Swiss Paediatric Oncology Group (SPOG) Scientific Committee: Prof. Dr. med. R. Ammann, Bern; Dr. med. R. Angst, Aarau; Prof. Dr. med. M. Ansari, Geneva; PD Dr. med. M. Beck Popovic, Lausanne; Dr. med. P. Brazzola, Bellinzona; Dr. med. J. Greiner, St. Gallen; Prof. Dr. med. M. Grotzer, Zurich; Dr. med. H. Hengartner, St. Gallen; Prof. Dr. med. T. Kuehne, Basel; Prof. Dr. med. C. Kuehni, Bern; Prof. Dr. med. K. Leibundgut, Bern; Prof. Dr. med. F. Niggli, Zurich; PD Dr. med. J. Rischewski, Lucerne; Prof. Dr. med. N. von der Weid, Basel.

Running title: Income and risk-of-poverty in parents of survivors

Key words: Income; poverty; parents; childhood cancer survivors; paediatric oncology; cohort

\section{Corresponding author:}

Gisela Michel, Department of Health Sciences and Health Policy, University of Lucerne, Frohburgstrasse 3, PO Box 4466, 6002 Luzern, Switzerland.

Phone:+41 41 2295955, Fax: +41 41 2295635, email: gisela.michel@unilu.ch

Cite as:

Mader L, Roser K, Baenziger J, Tinner EM, Scheinemann K, Kuehni CE, Michel G, for the Swiss Paediatric Oncology Group (SPOG). Household income and risk-of-poverty of parents of long-term childhood cancer survivors. Pediatr Blood Cancer. 2016;00:e26456. doi: 10.1002/pbc.26456. 
Abbreviations key

\begin{tabular}{ll}
\hline CCS & Childhood Cancer Survivors \\
\hline CHF & Swiss Francs \\
\hline CI & Confidence Interval \\
\hline CNS & Central Nervous System \\
\hline ICCC-3 & International Classification of Childhood Cancer - Third Edition \\
\hline LCH & Langerhans cell histiocytosis \\
\hline OR & Odds Ratio \\
\hline SCCR & Swiss Childhood Cancer Registry \\
\hline SCCSS & Swiss Childhood Cancer Survivor Study \\
\hline SD & Standard Deviation \\
\hline SHP & Swiss Household Panel \\
\hline
\end{tabular}

\begin{abstract}
Background: Taking care of children diagnosed with cancer affects parents' professional life and may place the family at risk-of-poverty. We aimed to i) compare the household income and risk-of-poverty of parents of childhood cancer survivors (CCS) with parents of the general population, and ii) to identify socio-demographic and cancer-related factors associated with risk-of-poverty.

Methods: As part of the Swiss Childhood Cancer Survivor Study, we sent a questionnaire to parents of CCS aged 5-15 years, who survived $\geq 5$ years after diagnosis. Information on parents of the general population came from the Swiss Household Panel (parents with $\geq 1$ child aged 5-15 years). Risk-ofpoverty was defined as having a monthly household income of $<4,500$ Swiss Francs (CHF) for single parents and $<6,000 \mathrm{CHF}$ for parent-couples. We used logistic regression to identify factors associated with risk-of-poverty.

Results: We included parents of 383 CCS and 769 control parent households. Parent-couples of CCS had a lower household income ( $\left.\mathrm{p}_{\text {trend }}<0.001\right)$ and were at higher risk-of-poverty $(30.4 \%$ vs. $19.3 \%$, $\mathrm{p}=0.001$ ) compared to control parent-couples. Household income and risk-of-poverty of single parents of CCS was similar to control single parents. Parents of CCS were at higher risk-of-poverty if they had only standard education $\left(\mathrm{OR}_{\text {mother }}=3.77\right.$, CI:1.61-8.82; $\mathrm{OR}_{\text {father }}=8.59$, CI:4.16-17.72) and were from German language region ( $\mathrm{OR}=1.99, \mathrm{CI}: 1.13-3.50)$. We found no cancer-related risk factors.

Conclusion: Parents of long-term childhood cancer survivors reported lower household income and higher risk-of-poverty than control parents. Support strategies may be developed to mitigate parents' risk-of-poverty in the long-term, particularly among parents with lower education.
\end{abstract}




\section{Introduction}

Experiencing a diagnosis of childhood cancer affects the whole family with wide-ranging psychosocial consequences for family members [1-3]. Managing the child's disease and treatment alongside everyday responsibilities can be highly challenging for parents. Several studies demonstrated that treatment-related work disruptions such as time off work, quitting or reducing workload are frequent among parents of childhood cancer patients [2-11]. These work disruptions resulted in substantial income losses [28]. Such losses together with non-medical out-ofpocket expenditures due to transportation or accommodation during the child's treatment may lead to severe financial strains for families of paediatric cancer patients [8, 12-17]. A study in the US including families of children with advanced cancer reported that about $15 \%$ of families fell below the poverty line due to these financial strains [5]. Identifying families at risk-of-poverty is important as poverty places children at risk of poor health outcomes [18].

After the child's recovery, income losses due to work disruptions which occurred during the child's cancer treatment may only have been partially compensated. In addition, long-term survivors are at high risk for chronic health conditions [19] requiring regular follow-up care. In Switzerland, more than $90 \%$ of parents are still actively involved in the follow-up care of survivors aged 11-17 years [20]. Dealing with survivors' medical and/or psychological sequelae may have an impact on parent's financial situation in the long-term. In Switzerland, we observed that parents of long-term survivors engage in more traditional parenting roles with more mothers not being employed and more fathers being full-time employed compared to the general population [21].

Understanding the long-term impact of childhood cancer on parents' financial situation is critical to guide family support strategies and to avoid adverse health outcomes even long after the child's recovery [22]. This is of particular concern in families with younger survivors requiring more parental care [23]. However, studies in parents of long-term survivors are rare. Therefore, we aimed to i) compare the household income and risk-ofpoverty of parents of long-term childhood cancer survivors aged 5-15 years with that of parents from the general population of Switzerland, and ii) to identify socio-demographic and cancer-related characteristics associated with risk-of-poverty.

\section{Methods}

\section{The Swiss Childhood Cancer Survivor Study (SCCSS)}

The Swiss Childhood Cancer Survivor Study (SCCSS) is a nationwide follow-up study of patients registered in the Swiss Childhood Cancer Registry (SCCR), who were diagnosed between 1976-2005, aged $<21$ years, and who survived $\geq 5$ years [24]. All children and adolescents at age of 0-20 years who were diagnosed with leukaemia, lymphoma, central nervous system (CNS) tumour, malignant solid tumours or Langerhans cell histiocytosis $(\mathrm{LCH})$ in Switzerland are registered in the SCCR [25, 26]. Survivors eligible for the SCCSS were contacted with a questionnaire between 2007 and 2012. For survivors aged $\leq 15$ years, parents were asked to complete the questionnaire between 2010 and 2011. We only included information collected in questionnaires sent to parents of survivors aged $\leq 15$ years. Parents of survivors living in an institution were excluded $(\mathrm{N}=3,0.7 \%$; Fig. 1). For each survivor, the parents completed one questionnaire including questions specifically addressing mothers or fathers. Ethical approval was granted through the Ethics Committee of the Canton of Bern to the SCCR and SCCSS (KEK-BE: 166/2014).

\section{Comparison group}

Control data was obtained from the Swiss Household Panel (SHP). The SHP is a nationwide computer-assisted telephone survey of a random sample of households in Switzerland being interviewed annually [27]. The aim of the SHP is to observe social changes in regard to living conditions and social representations in the Swiss population [27]. Data in the SHP are collected at the household and individual level. Three types of questionnaires were used: a grid questionnaire to assess the households' composition, a household questionnaire (completed by the households' reference person), and an individual questionnaire for all household members. For household members aged $<14$ years or members unable to respond, a proxy questionnaire is completed by the households' reference person [27]. For the present study, we used data from 2011 to match the year of data collection in parents of survivors. In total, 4,616 households responded to the grid questionnaire 
(91.8\%). Of those, 4,497 households completed the household questionnaire (97.4\%) including 9,241 individuals with a completed individual or proxy questionnaire $(83.9 \%)$. We restricted the SHP sample to households with $\geq 1$ child aged 5-15 years. Measurements

The questionnaire of the SCCSS was available in German, French, and Italian and had been created based on questionnaires used in US and UK childhood cancer survivor studies [28, 29]. We added questions on socio-economic measures adapted to Switzerland [30, 31].

\section{Outcome variables}

\section{Household income}

Parents of survivors were asked to select one of the following categories to report their monthly net household income in Swiss Francs (CHF): "0$4,500 ", \quad$ "4,501-6,000", "6,001-9,000", and ">9,000". Control parents were asked to report their yearly net household income in the SHP. The yearly household income was divided by 13 to obtain a monthly household income and categorised according to parents of survivors. We divided the yearly household income of control parents by 13 because the majority in Switzerland receive a 13th month's salary.

\section{Risk-of-poverty}

Risk-of-poverty was defined as having a monthly household income of $<4,500 \mathrm{CHF}$ for single parents and $<6,000 \mathrm{CHF}$ for parent-couples. These cut-offs were chosen because they are closest to the cut-offs for risk-of-poverty of the Swiss Federal Office of Statistics $(3,933 \mathrm{CHF}$ for single parents with two children aged $<14$ years and 5,163 CHF for parentcouples) $[32,33]$.

\section{Explanatory variables}

\section{Socio-demographic variables}

The following socio-demographic variables were assessed individually for mothers and fathers of survivors and control mothers and fathers: age at study $(<40$ years, $40-45$ years, $45-50$ years, $>50$ years), migration background, education, employment status, and number of children $(\leq 2$ children, $>2$ children). Mothers and fathers were considered to have a migration background if they were not Swiss citizens or moved to Switzerland after birth. Mothers' and fathers' education was divided into four categories: compulsory schooling, vocational training (including apprenticeship, grammar school, teachers' college), upper secondary education (higher technical and professional training, university of applied sciences), and university education [34]. Employment status was dichotomized into full-time employed and part-time/not employed. The language region (German, French/Italian) and living situation was assessed per household. The living situation was divided into parent-couples and single parents. Parent-couples included heterosexual couples such as biological parents, mothers/fathers with a new partner or adoptive parents. One homosexual couple was excluded for the analyses.

\section{Cancer-related variables}

We extracted cancer-related variables for survivors from the SCCR including: age at study ( $<9$ years, 912 years, $>12$ years), age at diagnosis $(<1$ year, $1-4$ years, $>4$ years), diagnosis, treatment, time since diagnosis ( $<8$ years, 8-11 years, $>11$ years), and relapse status. Diagnosis was coded according to the International Classification of Childhood Cancer Third Edition (ICCC-3) [35]. For analyses, diagnosis was categorized into: leukaemia, lymphoma, CNS tumours, soft tissue sarcoma/bone tumour, and other tumours. Treatment modalities were coded hierarchically into: surgery only, chemotherapy (may have had surgery), radiotherapy (may have had surgery and/or chemotherapy), and stem cell transplantation. Relapse status was coded as yes or no. Parents of survivors reported in the questionnaire if their child suffered from physical or psychological late effects attributable to cancer and/or its treatment (yes/no).

\section{Statistical analysis}

All analyses were performed using Stata version 14.1 (StataCorp LP, College Station, TX). For single parents of survivors, we only used information provided for the parent living with the survivor. To account for differences in parents' socio-demographic characteristics that were present before the child's diagnosis (Supplementary Table S1), we standardised control mothers' and fathers' on age at study, migration background, education, and the households' language region according to the marginal distribution in parents of survivors. We used multivariable logistic regression with being a control household as outcome to calculate appropriate weights [21]. The weight for parents of 
survivors was set to one. All analyses were based on weighted controls.

First, we used a combined dataset of parents of survivors and control parents to compare the household income and risk-of-poverty using chisquared tests and tests for trend across different income categories. This comparison was done for the total sample of parents of survivors and control parents and stratified by the parents' living situation (parent-couples/single parents). The risk-of-poverty was additionally compared stratified by the mothers' and fathers' education for both populations. Tests for trend were used to compare the risk-of-poverty across education categories. We fitted univariable and multivariable logistic regression models to determine associations between risk-of-poverty and being a parent of a survivor and socio-demographic variables in the combined dataset. Educational achievement was dichotomized into standard education (compulsory schooling, vocational training) and higher education (upper secondary education, university education) for all regression analyses. Interaction tests were used to determine whether associations with sociodemographic variables differed between parents of survivors and control parents.

Second, we investigated associations between risk-of-poverty and socio-demographic and cancerrelated variables in univariable and multivariable logistic regression in parents of survivors only. All variables associated with risk-of-poverty at $p<0.05$ in univariable regression were included in multivariable analyses. We used Wald tests to calculate global p-values. P-values $<0.05$ were considered statistically significant.

\section{Results}

\section{Characteristics of the study population}

Of 699 survivors eligible for the SCCSS, 603 parents could be contacted (Fig. 1). Of those, 453 (75.1\%) returned the questionnaire and 444 (73.6\%) were eligible for our study. Among eligible parents, we excluded parents with missing income data $(\mathrm{N}=61,13.7 \%)$ resulting in a final sample of 339 parent-couples and 44 single parents of survivors $(\mathrm{N}=42$ mothers; $\mathrm{N}=2$ fathers). Parents of survivors with missing income data were not significantly different from parents that reported their household income for all socio-demographic characteristics listed in Table 1 (all $\mathrm{p}>0.05$ ). Among controls $(\mathrm{N}=4,497$ households that completed the household questionnaire), we excluded households without children $(\mathrm{N}=2,772,61.6 \%)$, with no child aged 5-15 years $(\mathrm{N}=901,20.0 \%)$, and homosexual couples $(\mathrm{N}=1, \quad 0.02 \%)$ resulting in a sample of 823 households eligible for our study. After exclusion of households with missing income data $(\mathrm{N}=54,6.6 \%)$ the final control population consisted of 769 households. In controls, parent-couple households $(p=0.003)$ and households where the father was fulltime employed $(p=0.045)$ were less likely to report household income.

In both populations, the majority were parentcouple households. The mean age of mothers and fathers of survivors was 42.7 years $(\mathrm{SD}=4.7)$ and 45.9 years $(\mathrm{SD}=5.9)$, respectively, and $28.1 \%$ of mothers and $24.6 \%$ of fathers reported a migration background (Table 1). The majority of households were from the German language region. Control parents were standardised for these variables. More fathers of survivors were full-time employed than control fathers $(p<0.001)$. Leukaemia $(37.9 \%)$ was the most common cancer diagnosis followed by CNS tumours $(16.2 \%)$. The mean age at study of survivors was 12.1 years $(\mathrm{SD}=2.7)$ with a mean time since diagnosis of 9.1 years $(\mathrm{SD}=2.6)$. Fortytwo percent of parents reported that their child suffered from late effects and $10.2 \%$ of survivors had experienced a cancer relapse.

\section{Household income and risk-of-poverty of parents of survivors and control parents}

Parents of survivors reported a lower household income than control parents $\left(\mathrm{p}_{\text {trend }}<0.001\right)$. The majority of parents of survivors reported a household income between 6,001-9,000 Swiss Francs (CHF) per month ( $\mathrm{N}=132,34.5 \%$; Fig. 2), whereas among controls the majority reported a household income of $>9,000$ CHF (39.8\%). Stratified by living situation, we found that parentcouples had a lower household income compared to control parent-couples $\left(\mathrm{p}_{\text {trend }}<0.001\right)$. The household income of single parents of survivors was not significantly lower compared to control single parents $\left(\mathrm{p}_{\text {trend }}=0.189\right)$. However, no single parents of survivors reported having a household income of $>9,000$ CHF compared to $9.7 \%$ in control single parents. Compared to control parents, we observed a significantly higher risk-of-poverty for parentcouples of survivors $(19.3 \%$ versus $30.4 \%$; $p=0.001$; Fig. 2), however, not for single parents of survivors (35.6\% versus $36.4 \%$; $p=0.936$ ). 


\section{Socio-demographic determinants of risk-of- poverty in parents of survivors and control parents}

In the combined dataset we found that parents of survivors were more often at risk-of-poverty than control parents in both univariable (Supplementary Table S2) and multivariable regression (Table 2; $\mathrm{OR}=1.86$, CI:1.32-2.62). In multivariable analysis, households were at lower risk-of-poverty if the father was aged 45-50 years $(\mathrm{OR}=0.49$, CI:0.26$0.90)$. Higher risk-of-poverty was found if the father was not or only part-time employed $(\mathrm{OR}=2.87$, CI:1.58-5.23) and if the mother or father had standard education with a stronger effect for the fathers' education $\left(\mathrm{OR}_{\text {mother }}=3.70\right.$, CI:2.15-6.36; $\left.\mathrm{OR}_{\text {father }}=7.50, \quad \mathrm{CI}: 4.62-12.18\right)$. Stratification by parents' education revealed a gradual decrease of the risk-of-poverty with higher educational achievement for both, mothers and fathers of survivors and controls (all $\mathrm{p}_{\text {trend }}<0.001$; Fig. 3). Associations between socio-demographic characteristics and risk-of-poverty were similar for parents of survivors and control parents (all $p_{\text {interaction }}$ $>0.05)$.

\section{Socio-demographic and cancer-related determinants of risk-of-poverty in parents of survivors}

In univariable regression analyses among parents of survivors only, we found no significant associations between cancer-related characteristics and risk-ofpoverty (Supplementary Table S3). In multivariable analysis, a higher risk-of-poverty was observed if parents had standard education with a stronger effect for fathers' education (Table 3; $\mathrm{OR}_{\text {mother }}=3.77$, CI:1.61-8.82; $\mathrm{OR}_{\text {father }}=8.59$, CI:4.16-17.72). A lower risk-of-poverty was observed in households from French/Italian language region $(\mathrm{OR}=0.50, \mathrm{CI}: 0.29$ 0.89 ) and households where fathers were aged 4550 years $(\mathrm{OR}=0.39$, CI:0.17-0.91).

\section{Discussion}

This study highlights that a child's cancer diagnosis impacts on parents' long-term financial situation, evidenced by a lower household income reported by parents of survivors compared to control parents. However, we found no diagnosis- or treatmentrelated determinants of risk-of-poverty. Similar to controls, being at risk-of-poverty was mainly determined by the parents' educational achievement.
Previous studies suggested that parents of survivors encounter substantial income losses and a high financial burden at the time of diagnosis and during treatment [2-8]. However, studies investigating the long-term impact are rare. We showed that parents of survivors had a lower household income than control parents long after treatment ended, even after standardizing for sociodemographic characteristics. In contrast, a longitudinal study in Sweden showed that parents' household income was reduced during the child's treatment, while similar income levels as before diagnosis were reported one year after treatment [2]. A Norwegian study showed that earning losses among parents of survivors tend to increase $\geq 5$ years after diagnosis [1]. However, the authors concluded that the overall effects on parents' earnings were minor. A Swedish study showed that mothers of survivors experienced disadvantages in their professional life years after the child's diagnosis whereas fathers' income was reestablished after a few years [36]. These conflicting findings may be explained by the generous welfare options and flexible labour market policies typical for Scandinavian countries. In Switzerland, opportunities for paid leave to care for ill children are limited [21] although the average time parents need for caretaking of children with cancer has been estimated to add up to approximately 240 working days in Switzerland [37]. Parents of survivors may therefore not be able to re-establish or compensate work and income disruptions that occurred during the child's treatment.

The implications of a lower household income were further emphasized by the substantial proportion of households at risk-of-poverty. We observed a higher risk-of-poverty for parents of survivors compared to controls with single parents showing higher risk-of-poverty in both groups. Single parenthood was identified as a risk factor for economic hardship shortly after diagnosis in an Australian study [3]. Our findings suggest that in the long term the cancer diagnosis does not add to the increased risk-of-poverty. Alimony payments or governmental subsidies as well as limited workrelated flexibility of single parents may explain these findings. According to the Swiss Federal Office of Statistics people are at risk-of-poverty if their disposable income is less than $60 \%$ of the median standard income $[32,33]$. This amount has to cover general living costs (e.g. food, clothing, or mobility), housing costs and other expenses such as insurances [33]. A study in the US concluded that 
household material hardship in families of children undergoing chemotherapy increased to about 30\% following six months of treatment [22]. Another study in the US including families of children with advanced cancer reported that about $15 \%$ of families fell below the poverty line due to financial strains related to the child's disease [5]. However, comparability with US studies is limited due to shorter follow-up periods and large differences between the respective health or welfare systems. Nevertheless, early identification and targeted interventions for families of survivors at risk-ofpoverty are crucial as further income deteriorations may predispose these families for slipping into poverty and material hardship [38].

Only few studies investigated how sociodemographic characteristics determine the risk-ofpoverty of parents of survivors in the long-term. In our study, similar to control parents, being at riskof-poverty was mainly determined by the parents' educational achievement. About $60 \%$ of parents of survivors with compulsory schooling only were at risk-of-poverty compared to less than $15 \%$ among those with upper secondary education. This is in line with national estimates showing that people with no post-compulsory education were twice as likely to be poor compared to those with upper secondary education [33]. In our study, lower education of the father lead to an 8-fold increase in the risk-of-poverty compared to a 4-fold increase if the mother had low education. Syse and colleagues observed decreased earnings among mothers with higher education in Norway whereas the father's earnings were not affected by education [1]. In Switzerland, mothers typically adopt the role of primary caregiver. In a previous study, we showed that parents of long-term survivors engage in more pronounced traditional parenting roles with more mothers being not employed and more fathers being full-time employed [21]. We found that households of parents of survivors and control parents were at higher risk-of-poverty if the father was not or only part-time employed. These findings highlight the importance of the parent's educational achievement and employment situation, particularly among fathers of survivors because fathers may be more often in charge of guaranteeing the household's financial stability. Parents of survivors from the French/Italian language region were less likely to be at risk-of-poverty in our study. We are not aware of studies that analysed the association between country regions and the risk-of-poverty with national estimates showing only weak evidence for regional differences [32].

In terms of cancer-related determinants of riskof-poverty, we found no associations with diagnosis- or treatment-related characteristics. This is in line with a Swedish study showing that household income was not determined by illnessrelated factors one year after diagnosis [2]. Cancer severity and prognosis did also not affect parent's earnings in a study in Norway [1]. However, they observed significant reductions in earnings for mothers of children with CNS cancers, germinal cell cancers, and leukaemia [1]. The absence of such associations in our study may be partially explained by the longer time since diagnosis. Our data suggest that parents stay at risk-of-poverty for a long time; even $>11$ years after diagnosis we found no decrease in the parents' risk-of-poverty. The observed impact on income and risk-of-poverty in our study may therefore rather be due to other factors such as altered personal career choices, declined job opportunities or missed promotions after the child's diagnosis that need to be explored in future studies.

\section{Limitations and strengths}

A limitation of our study was the restriction to parents of survivors aged 5-15 years, which reduces the generalizability of our findings. However, a population-based sampling approach with high response rates $(>75 \%)$ was used for parents of survivors and control parents. The cross-sectional nature of our study did not enable an examination of parents' financial situation along the child's disease trajectory which needs to be clarified in follow-up studies. Differences in household income between parents of survivors and control parents may be underestimated since we divided the yearly income of control parents by 13 to obtain a monthly income. A $13^{\text {th }}$ month's salary is common in Switzerland, however, may not be true for all control parents. Self-reported income data may also differ by assessment methods (questionnaire vs. telephone interview) and be subject to item-nonresponse [39]. The literature suggests that item-nonresponse in questions on income is not completely at random and tends to be selective to both tails of the income distribution [39]. In our study, non-responding parents of survivors were not significantly different from responders. However, household income among controls may be overestimated as nonresponders were more likely to be parent-couple 
households and households where the father is fulltime employed. However, we maximized the comparability of the two populations by weighting control parents according to parents of survivors. Both surveys were performed in the same time period and thereby differences caused by global economic circumstances (e.g. recession in 2008) could be avoided. Since the questionnaire to parents of survivors focused on the survivor, no in-depth information on parents' financial situation was available (e.g. degree of material hardship, lifestyle changes or governmental support). These aspects need to be further explored in future studies.

\section{Conclusion}

In conclusion, this study highlights that a child's cancer diagnosis impacts on parents' long-term financial situation. Interventions and policies aiming to provide more flexible working conditions, extended sick leaves and better return-to-work opportunities for parents of survivors may improve the parent's long-term financial situation by having more stable income sources. Such support strategies may be promoted to mitigate parents' risk-ofpoverty in the long-term, particularly among parents with lower education.

\section{Acknowledgements}

We thank all parents of survivors for participating in our survey, and the Swiss Centre of Expertise in the Social Sciences (FORS) for providing data for the Swiss Household Panel 2011. We thank the study team of the Swiss Childhood Cancer Survivor Study (Erika Brantschen Berclaz, Micòl Gianinazzi, Laura Wengenroth, Corina Rueegg, Cornelia Rebholz), the data managers of the Swiss Paediatric Oncology Group (Claudia Anderegg, Nadja Beusch, RosaEmma Garcia, Franziska Hochreutener, Friedgard Julmy, Nadine Lanz, Heike Markiewicz, Genevieve Perrenoud, Annette Reinberger, Renate Siegenthaler, Verena Stahel), and the team of the Swiss Childhood Cancer Registry (Verena Pfeiffer, Vera Mitter, Elisabeth Kiraly, Marlen Spring, Christina Krenger, Priska Wölfli).

This study was financially supported by the Swiss National Science Foundation (SNF Grant No. 100019153268 / 1; Ambizione Grant to GM: PZ00P3 121682/1 and PZ00P3-141722). The Swiss Childhood Cancer Survivor Study was funded by the Swiss Cancer League (KLS-2215-02-2008, KLS-02631-08-2010, KLS-02783-02-2011, KLS-
3412-02-2014). The work of the Swiss Childhood Cancer Registry is supported by the Swiss Paediatric Oncology Group (www.spog.ch), Schweizerische Konferenz der kantonalen Gesundheitsdirektorinnen und -direktoren (www.gdk-cds.ch), Swiss Cancer Research (www.krebsforschung.ch), Kinderkrebshilfe Schweiz (www.kinderkrebshilfe.ch), Ernst-Göhner Stiftung, Stiftung Domarena and National Institute of Cancer Epidemiology and Registration (www.nicer.ch).

\section{Conflict of interest statement}

No conflict of interest stated for any of the authors.

\section{References}

1. Syse A, Larsen IK, Tretli S. Does cancer in a child affect parents' employment and earnings? A population-based study. Cancer Epidemiol 2011;35: 298-305.

2. Hoven E, von Essen L, Norberg AL. A longitudinal assessment of work situation, sick leave, and household income of mothers and fathers of children with cancer in Sweden. Acta Oncol 2013;52: 1076-85.

3. Heath JA, Lintuuran RM, Rigguto G, Tokatlian N, McCarthy M. Childhood cancer: its impact and financial costs for Australian families. Pediatr Hematol Oncol 2006;23: 439-48.

4. Limburg H, Shaw AK, McBride ML. Impact of childhood cancer on parental employment and sources of income: a Canadian pilot study. Pediatr Blood Cancer 2008;51: 93-8.

5. Bona K, Dussel V, Orellana L, Kang T, Geyer R, Feudtner C, Wolfe J. Economic impact of advanced pediatric cancer on families. J Pain Symptom Manage 2014;47: 594-603.

6. Aung L, Saw SM, Chan MY, Khaing T, Quah TC, Verkooijen HM. The hidden impact of childhood cancer on the family: a multi-institutional study from Singapore. Ann Acad Med Singapore 2012;41: 170-5.

7. Okada H, Maru M, Maeda R, Iwasaki F, Nagasawa M, Takahashi M. Impact of Childhood Cancer on Maternal Employment in Japan. Cancer Nurs 2014;0: 1-8.

8. Eiser C, Upton P. Costs of caring for a child with cancer: a questionnaire survey. Child Care Health Dev 2007;33: 455-9.

9. Lau S, Lu X, Balsamo L, Devidas M, Winick N, Hunger SP, Carroll W, Stork L, Maloney K, KadanLottick N. Family life events in the first year of acute lymphoblastic leukemia therapy: a children's 
oncology group report. Pediatr Blood Cancer 2014;61: 2277-84.

10. Fluchel MN, Kirchhoff AC, Bodson J, Sweeney C, Edwards SL, Ding Q, Stoddard GJ, Kinney AY. Geography and the burden of care in pediatric cancers. Pediatr Blood Cancer 2014;61: 1918-24.

11. Mostert S, Sitaresmi MN, Gundy CM, Sutaryo, Veerman AJ. Parental experiences of childhood leukemia treatment in indonesia. J Pediatr Hematol Oncol 2008;30: 738-43.

12. Tsimicalis A, Stevens B, Ungar WJ, McKeever P, Greenberg M, Agha M, Guerriere D, Naqvi A, Barr R. A mixed method approach to describe the out-ofpocket expenses incurred by families of children with cancer. Pediatr Blood Cancer 2013;60: 438-45.

13. Cohn RJ, Goodenough B, Foreman T, Suneson J. Hidden financial costs in treatment for childhood cancer: an Australian study of lifestyle implications for families absorbing out-of-pocket expenses. J Pediatr Hematol Oncol 2003;25: 854-63.

14. Barr R, Furlong W, Horsman J, Feeny D, Torrance G, Weitzman S. The monetary costs of childhood cancer to the families of patients. Int $\mathrm{J}$ Oncol 1996;8: 933-40.

15. Bloom BS, Knorr RS, Evans AE. The epidemiology of disease expenses. The costs of caring for children with cancer. JAMA 1985;253: 2393-7.

16. Lansky SB, Cairns NU, Clark GM, Lowman J, Miller L, Trueworthy R. Childhood cancer: nonmedical costs of the illness. Cancer 1979;43: 403-8.

17. Dockerty JD, Skegg DC, Williams SM. Economic effects of childhood cancer on families. J Paediatr Child Health 2003;39: 254-8.

18. Wood D. Effect of child and family poverty on child health in the United States. Pediatrics 2003;112: 707-11.

19. Oeffinger KC, Mertens AC, Sklar CA, Kawashima T, Hudson MM, Meadows AT, Friedman DL, Marina N, Hobbie W, Kadan-Lottick NS, Schwartz CL, Leisenring W, Robison LL, Childhood Cancer Survivor S. Chronic health conditions in adult survivors of childhood cancer. $N$ Engl $J$ Med 2006;355: 1572-82.

20. Vetsch J, Rueegg CS, Mader L, Bergstraesser E, Rischewski J, Kuehni CE, Michel G, Swiss Paediatric Oncology G. Follow-up care of young childhood cancer survivors: attendance and parental involvement. Support Care Cancer 2016;24: 312738.

21. Mader L, Rueegg CS, Vetsch J, Rischewski J, Ansari M, Kuehni CE, Michel G, Swiss Paediatric Oncology G. Employment Situation of Parents of Long-Term Childhood Cancer Survivors. PloS one 2016;11: e0151966.

22. Bona K, London WB, Guo D, Frank DA, Wolfe J. Trajectory of Material Hardship and Income Poverty in Families of Children Undergoing
Chemotherapy: A Prospective Cohort Study. Pediatr Blood Cancer 2016;63: 105-11.

23. Pagano E, Baldi I, Mosso ML, di Montezemolo LC, Fagioli F, Pastore G, Merletti F. The economic burden of caregiving on families of children and adolescents with cancer: a population-based assessment. Pediatr Blood Cancer 2014;61: 108893.

24. Kuehni CE, Rueegg CS, Michel G, Rebholz CE, Strippoli MP, Niggli FK, Egger M, von der Weid NX, Swiss Paediatric Oncology G. Cohort profile: the Swiss childhood cancer survivor study. Int J Epidemiol 2012;41: 1553-64.

25. Michel G, von der Weid NX, Zwahlen M, Redmond S, Strippoli MP, Kuehni CE, Swiss Paediatric Oncology G. Incidence of childhood cancer in Switzerland: the Swiss Childhood Cancer Registry. Pediatr Blood Cancer 2008;50: 46-51.

26. Michel G, von der Weid NX, Zwahlen M, Adam M, Rebholz CE, Kuehni CE, Swiss Childhood Cancer R, Swiss Paediatric Oncology Group Scientific C. The Swiss Childhood Cancer Registry: rationale, organisation and results for the years 2001-2005. Swiss Med Wkly 2007;137: 502-9.

27. Voorpostel M, Tillmann R, Lebert F, Kuhn U, Lipps O, Ryser V-A, Schmid F, Antal E, Werni B (2014). Swiss Household Panel Userguide (19992013), Wave 15, December 2014. Lausanne: FORS.

28. Robison LL, Armstrong GT, Boice JD, Chow EJ, Davies SM, Donaldson SS, Green DM, Hammond S, Meadows AT, Mertens AC, Mulvihill JJ, Nathan PC, Neglia JP, Packer RJ, Rajaraman P, Sklar CA, Stovall M, Strong LC, Yasui Y, Zeltzer LK. The Childhood Cancer Survivor Study: a National Cancer Institute-supported resource for outcome and intervention research. J Clin Oncol 2009;27: 2308-18.

29. Hawkins MM, Lancashire ER, Winter DL, Frobisher C, Reulen RC, Taylor AJ, Stevens MC, Jenney M. The British Childhood Cancer Survivor Study: Objectives, methods, population structure, response rates and initial descriptive information. Pediatr Blood Cancer 2008;50: 1018-25.

30. Lieberherr R, Marquis J-F, Storni M, Wiedenmayer G. Gesundheit und Gesundheitsverhalten in der Schweiz $2007 \quad$ - $\quad$ Schweizerische Gesundheitsbefragung [Health and health behaviour in Switzerland 2007 - Swiss Health Survey]. Neuchâtel: Bundesamt für Statistik; 2010.

31. Germann U. Eidgenössische Volkszählung 2000 Abschlussbericht zur Volkszählung 2000 [Swiss Census 2000 - Final report]. Neuchâtel: Bundesamt für Statistik; 2005.

32. Bundesamt für Statistik. Armut in der Schweiz: Konzepte, Resultate und Methode - Ergebnisse auf der Basis von SILC 2008 bis 2010 [Poverty in Switzerland: concepts, results and methods]. Neuchâtel: 2012. 
33. Bundesamt für Statistik. Armut und materielle Entbehrung - Ergebnisse 2007 bis 2014 [Poverty and material deprivation - results from 2007 to 2014]. Neuchâtel: 2016.

34. Kuehni CE, Strippoli MP, Rueegg CS, Rebholz CE, Bergstraesser E, Grotzer M, von der Weid NX, Michel G, Swiss Pediatric Oncology G. Educational achievement in Swiss childhood cancer survivors compared with the general population. Cancer 2012;118: 1439-49.

35. Steliarova-Foucher E, Stiller C, Lacour B, Kaatsch P. International Classification of Childhood Cancer, third edition. Cancer 2005;103: 1457-67.

36. Lindahl Norberg A, Montgomery SM, Bottai M, Heyman M, Hoven EI. Short-term and long-term effects of childhood cancer on income from employment and employment status: A national cohort study in Sweden. Cancer 2016.

37. Schindler M, Kuehni C. Betreuungsaufwand für Eltern von Kindern und Jugendlichen mit Krebs in der Schweiz. Schweizer Kinderkrebsregister, Institut für Sozial- und Präventivmedizin, Universität Bern, 2014.

38. Pelletier W, Bona K. Assessment of Financial Burden as a Standard of Care in Pediatric Oncology. Pediatr Blood Cancer 2015;62 Suppl 5: S619-31.

39. Lipps O (2014). Income imputation in the Swiss Household Panel 1999-2007. FORS Working Paper Series, paper 2010-1. Lausanne: FORS. 
TABLE 1 Characteristics of parents of survivors and weighted control parents

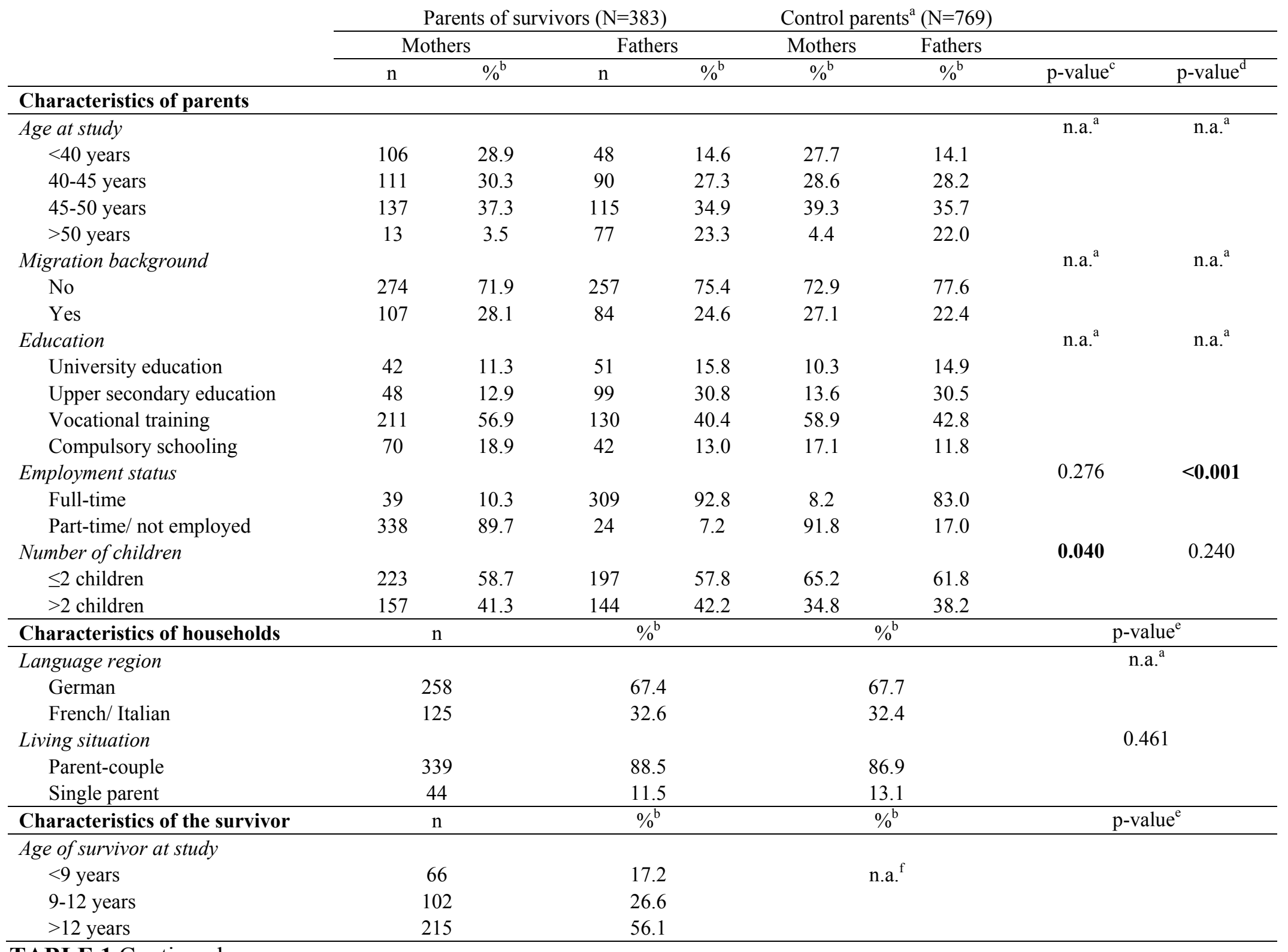

TABLE 1 Continued 


\begin{tabular}{|c|c|c|c|c|}
\hline & $\mathrm{n}$ & $\%^{\mathrm{b}}$ & $\%^{\mathrm{b}}$ & p-value ${ }^{e}$ \\
\hline \multicolumn{5}{|l|}{ Age at diagnosis } \\
\hline$<1$ year & 86 & 22.5 & n.a. ${ }^{f}$ & \\
\hline $1-4$ years & 184 & 48.0 & & \\
\hline$>4$ years & 113 & 29.5 & & \\
\hline \multicolumn{5}{|l|}{ Diagnosis (ICCC-3) } \\
\hline Leukaemia & 145 & 37.9 & n.a. ${ }^{f}$ & \\
\hline Lymphoma & 25 & 6.5 & & \\
\hline CNS tumour & 62 & 16.2 & & \\
\hline Neuroblastoma & 35 & 9.1 & & \\
\hline Retinoblastoma & 31 & 8.1 & & \\
\hline Renal tumour & 33 & 8.6 & & \\
\hline Hepatic tumour & 8 & 2.1 & & \\
\hline Bone tumour & 5 & 1.3 & & \\
\hline Soft tissue sarcoma & 19 & 5.0 & & \\
\hline Germ cell tumour & 9 & 2.4 & & \\
\hline Langerhans cell histiocytosis & 9 & 2.4 & & \\
\hline Other tumours ${ }^{\mathrm{g}}$ & 2 & 0.5 & & \\
\hline \multicolumn{5}{|l|}{ Treatment } \\
\hline Surgery & 63 & 16.5 & n.a. ${ }^{f}$ & \\
\hline Chemotherapy & 237 & 62.2 & & \\
\hline Radiotherapy & 60 & 15.8 & & \\
\hline Stem cell transplantation & 21 & 5.5 & & \\
\hline \multicolumn{5}{|l|}{ Time since diagnosis } \\
\hline$<8$ years & 160 & 41.8 & n.a. ${ }^{f}$ & \\
\hline $8-11$ years & 132 & 34.5 & & \\
\hline$>11$ years & 91 & 23.8 & & \\
\hline \multicolumn{5}{|l|}{ Relapse } \\
\hline No & 344 & 89.8 & n.a. ${ }^{f}$ & \\
\hline Yes & 39 & 10.2 & & \\
\hline \multicolumn{5}{|l|}{ Parent-reported late effects } \\
\hline No & 202 & 57.7 & n.a. ${ }^{f}$ & \\
\hline Yes & 148 & 42.3 & & \\
\hline
\end{tabular}

Abbreviations: CNS, central nervous system; ICCC-3, International Classification of Childhood Cancer - Third Edition; n.a., not applicable; n, number. Bold, p-value lower than 0.05 .

aCalculated on weighted analysis (weights on mothers' and fathers' age at study, migration background, education, and the households' language region).

${ }^{\text {b} P e r c e n t a g e s ~ a r e ~ b a s e d ~ u p o n ~ a v a i l a b l e ~ d a t a ~ f o r ~ e a c h ~ v a r i a b l e . ~}$

${ }^{\mathrm{c}} \mathrm{P}$-value calculated from chi-square statistics comparing mothers of survivors to control mothers. 
${ }^{\mathrm{d}} \mathrm{P}$-value calculated from chi-square statistics comparing fathers of survivors to control fathers.

${ }^{\mathrm{e}} \mathrm{P}$-value calculated from chi-square statistics comparing households of parents of survivors to households of control parents.

${ }^{\mathrm{f}}$ Cancer-related information is not applicable for control parents.

${ }^{\mathrm{g}}$ Other malignant epithelial neoplasms, malignant melanomas, and other or unspecified malignant neoplasms. 
TABLE 2 Socio-demographic determinants of risk-of-poverty ${ }^{\mathrm{a}}$ from multivariable ${ }^{\mathrm{b}}$ logistic regression models (combined dataset including parents of survivors and control parents ${ }^{\mathrm{c}}$ )

\begin{tabular}{|c|c|c|c|c|}
\hline & \multicolumn{4}{|c|}{ Parents of survivors $(\mathrm{N}=383)$ and control parents $(\mathrm{N}=769)$} \\
\hline & $\mathrm{OR}^{\mathrm{d}}$ & $95 \% \mathrm{CI}$ & p-value ${ }^{e}$ & p-value interaction ${ }^{\mathrm{e}, \mathrm{f}}$ \\
\hline Population & & & $<0.001$ & - \\
\hline Control parents & 1.00 & & & \\
\hline Parents of survivors & 1.86 & $1.32-2.62$ & & \\
\hline \multicolumn{5}{|l|}{ Characteristics of parents } \\
\hline Age at study mother & & & 0.541 & - \\
\hline$<40$ years & 1.00 & & & \\
\hline $40-45$ years & 1.04 & $0.59-1.85$ & & \\
\hline $45-50$ years & 0.78 & $0.48-1.28$ & & \\
\hline$>50$ years & 0.70 & $0.27-1.86$ & & \\
\hline Age at study father & & & 0.046 & - \\
\hline$<40$ years & 1.00 & & & \\
\hline $40-45$ years & 0.60 & $0.30-1.20$ & & \\
\hline $45-50$ years & 0.49 & $0.26-0.90$ & & \\
\hline$>50$ years & 0.88 & $0.43-1.82$ & & \\
\hline Migration background mother & & & 0.766 & - \\
\hline No & 1.00 & & & \\
\hline Yes & 1.07 & $0.70-1.63$ & & \\
\hline Migration background father & & & 0.150 & - \\
\hline No & 1.00 & & & \\
\hline Yes & 1.40 & $0.89-2.20$ & & \\
\hline Education mother & & & $<0.001$ & - \\
\hline Higher education & 1.00 & & & \\
\hline Standard education & 3.70 & $2.15-6.36$ & & \\
\hline Education father & & & $<0.001$ & - \\
\hline Higher education & 1.00 & & & \\
\hline Standard education & 7.50 & $4.62-12.18$ & & \\
\hline Employment status father & & & 0.001 & - \\
\hline Full-time & 1.00 & & & \\
\hline Part-time/ not employed & 2.87 & $1.58-5.23$ & & \\
\hline
\end{tabular}

Abbreviations: CI, confidence interval; n, number; OR, odds ratio. Bold, p-value lower than 0.05 .

${ }^{a}$ Risk-of-poverty was defined as having a monthly household income of $<4500$ Swiss Francs (CHF) for single parents and $<6000$ CHF for parent-couples.

${ }^{\mathrm{b}}$ All variables significantly $(\mathrm{p}<0.05)$ associated with being at risk-of-poverty in univariable regression were included in the multivariable model.

'Calculated on weighted analysis (weights on mothers' and fathers' age at study, migration background, education, and the households' language region).

${ }^{\mathrm{d}} \mathrm{OR}$ for being at risk-of-poverty.

${ }^{\mathrm{e}}$ Global p-value calculated from Wald tests.

${ }^{\mathrm{f}} \mathrm{P}$-value for interaction between parents of survivors and control parents. 
TABLE 3 Socio-demographic and cancer-related determinants of risk-of-poverty ${ }^{\mathrm{a}}$ from multivariable ${ }^{\mathrm{b}}$ logistic regression models in parents of survivors

\begin{tabular}{|c|c|c|c|}
\hline & \multicolumn{3}{|c|}{ Parents of survivors $(\mathrm{N}=383)$} \\
\hline & $\mathrm{OR}^{\mathrm{c}}$ & $95 \% \mathrm{CI}$ & $\mathrm{p}$-value \\
\hline \multicolumn{4}{|l|}{ Characteristics of parents } \\
\hline Age at study father & & & 0.031 \\
\hline$<40$ years & 1.00 & & \\
\hline $40-45$ years & 0.40 & $0.16-0.99$ & \\
\hline $45-50$ years & 0.39 & $0.17-0.91$ & \\
\hline$>50$ years & 0.91 & $0.38-2.21$ & \\
\hline Migration background father & & & 0.223 \\
\hline No & 1.00 & & \\
\hline Yes & 1.47 & $0.79-2.74$ & \\
\hline Education mother & & & 0.002 \\
\hline Higher education & 1.00 & & \\
\hline Standard education & 3.77 & $1.61-8.82$ & \\
\hline Education father & & & $<0.001$ \\
\hline Higher education & 1.00 & & \\
\hline Standard education & 8.59 & $4.16-17.72$ & \\
\hline Employment status father & & & 0.184 \\
\hline Full-time & 1.00 & & \\
\hline Part-time/ not employed & 2.02 & $0.72-5.66$ & \\
\hline \multicolumn{4}{|l|}{ Characteristics of households } \\
\hline Language region & & & 0.018 \\
\hline German & 1.00 & & \\
\hline French/Italian & 0.50 & $0.29-0.89$ & \\
\hline
\end{tabular}

Abbreviations: CI, confidence interval; $n$, number; OR, odds ratio. Bold, p-value lower than 0.05 .

${ }^{a}$ Risk-of-poverty was defined as having a monthly household income of $<4500$ Swiss Francs (CHF) for single parents and $<6000 \mathrm{CHF}$ for parent-couples.

${ }^{\mathrm{b}}$ All variables significantly $(\mathrm{p}<0.05)$ associated with being at risk-of-poverty in univariable regression were included in the multivariable model.

${ }^{c} \mathrm{OR}$ for being at risk-of-poverty.

${ }^{\mathrm{d}}$ Global p-value calculated from Wald tests. 
Figure 1 Participants of the parents' questionnaire of the Swiss Childhood Cancer Survivor Study

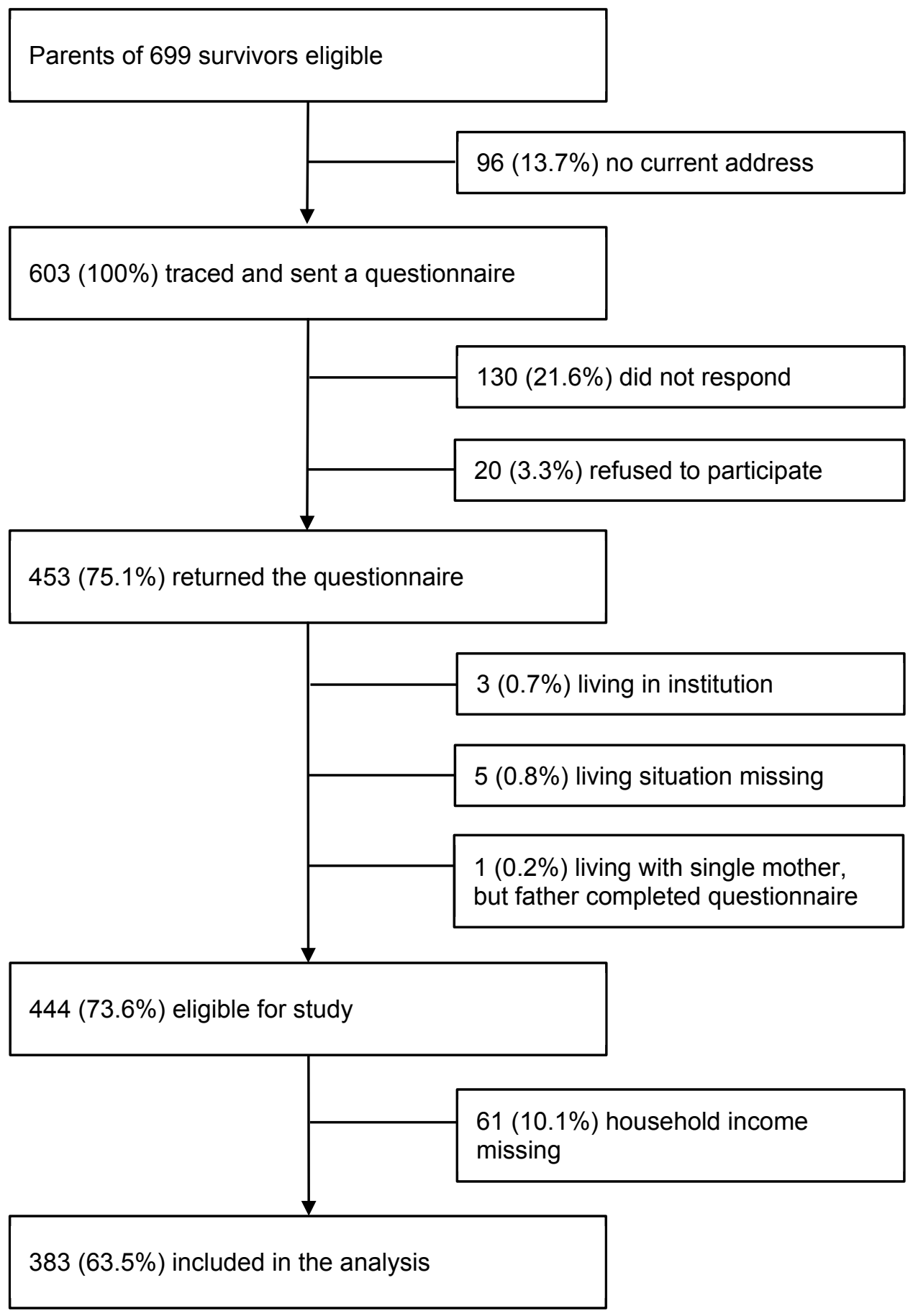

Flow diagram of our study population starting from those eligible in the Swiss Childhood Cancer Registry to those included in the analysis. 
Figure 2 Household income and risk-of-poverty of parents of survivors compared to control parents
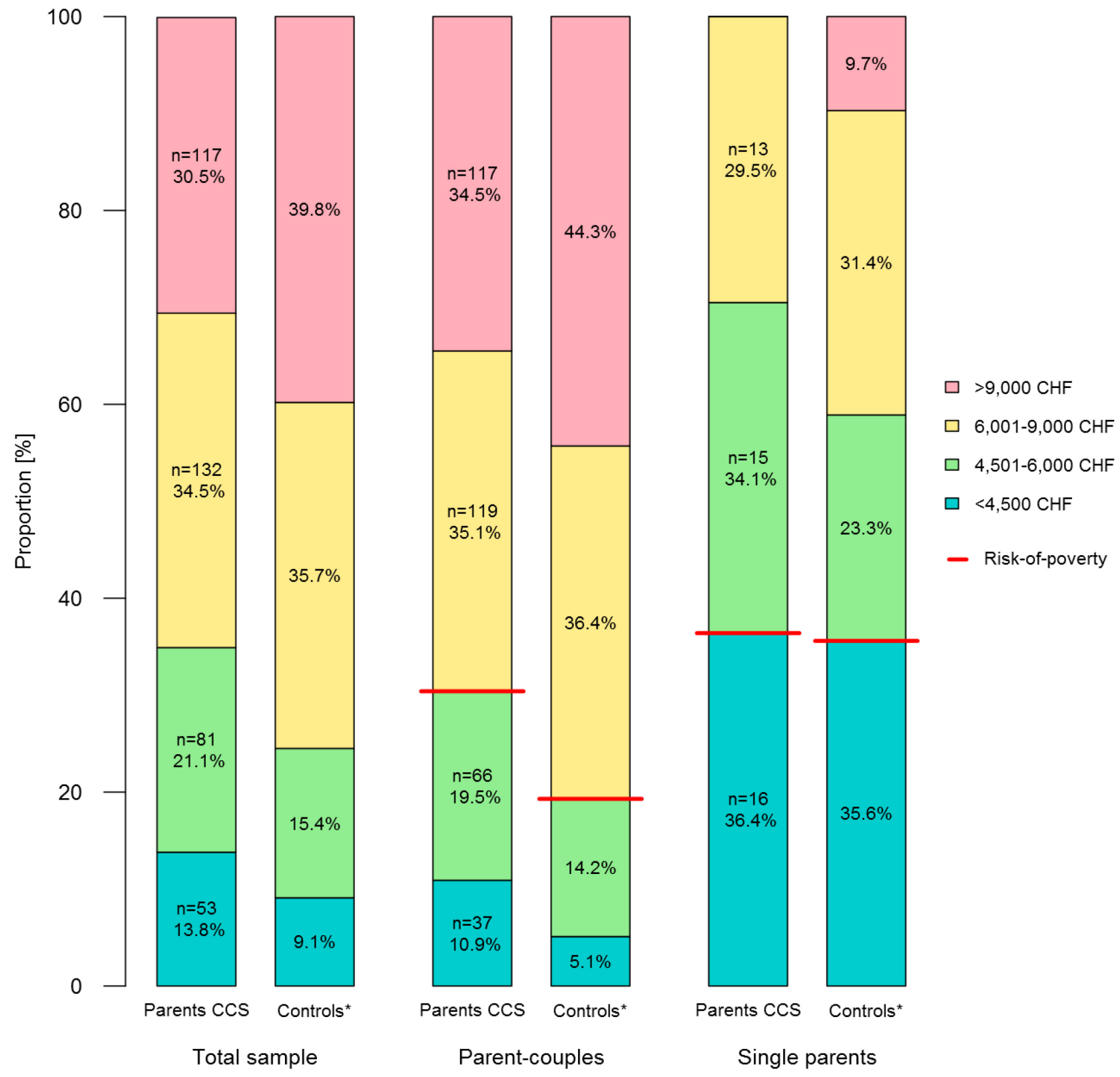

Comparison of the household income and risk-of-poverty of parents of childhood cancer survivors (CCS) and control parents for the total sample and stratified by parents' living situation (parentcouples vs. single parents). The numbers in the figure represent the number and the proportion of households which reported the respective household income; the red line indicates the cut-off for riskof-poverty.

*Calculated on weighted analysis (weights on mothers' and fathers' age at study, migration background, education, and the households' language region).

Abbreviations: CCS, childhood cancer survivors; CHF, Swiss Francs. 
FIGURE 3 Risk-of-poverty of parents of survivors and control parents stratified by mothers' and fathers' education
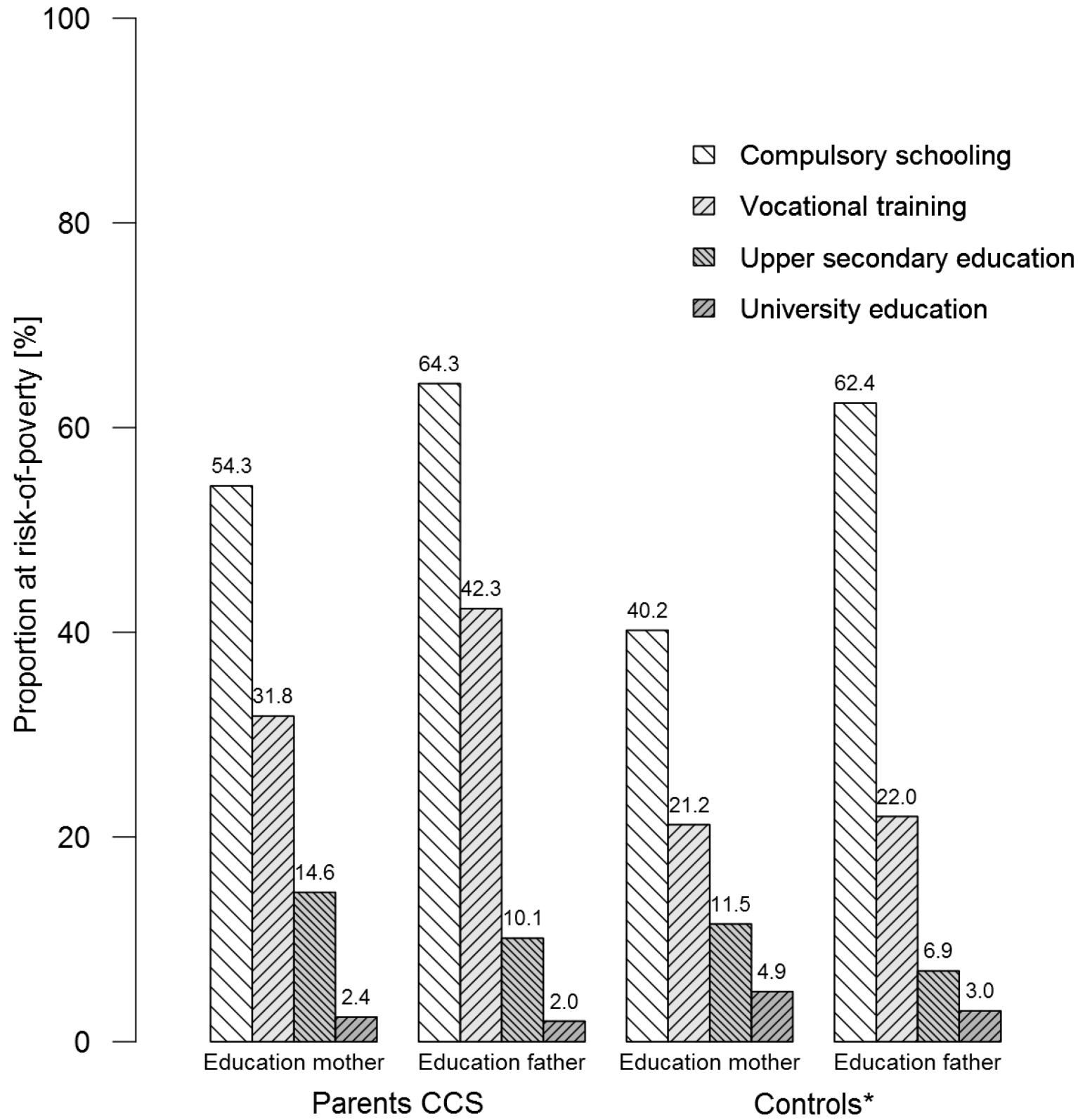

Comparison of the risk-of-poverty of parents of childhood cancer survivors (CCS) and control parents stratified by the mothers' and fathers' education. The proportion at risk-of-poverty refers to the number of mothers or fathers with the respective education.

*Calculated on weighted analysis (weights on mothers' and fathers' age at study, migration background, education, and the households' language region).

Abbreviations: CCS, childhood cancer survivors. 
SUPPLEMENTARY TABLE S1 Socio-demographic characteristics of parents of survivors and control parents

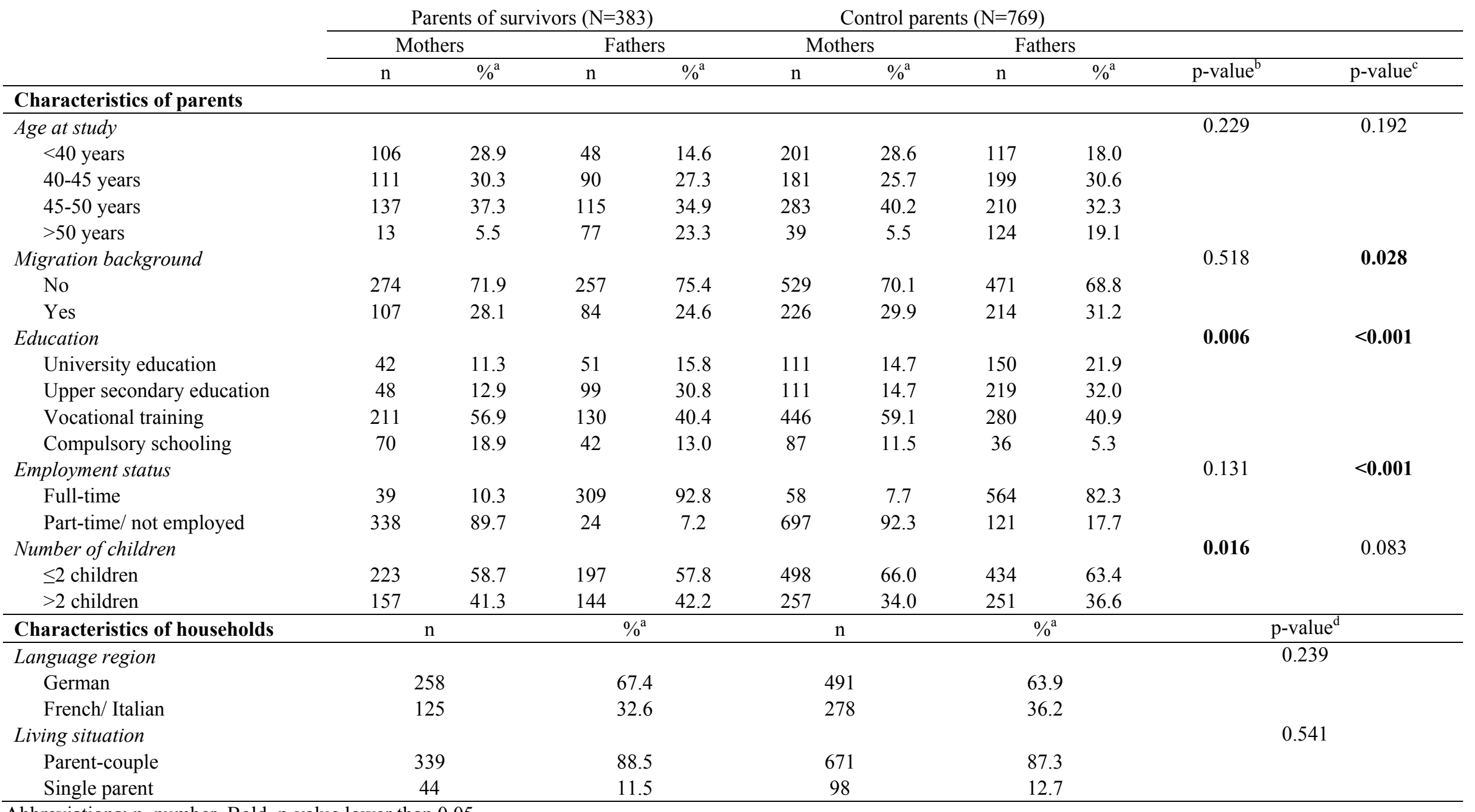

Abbreviations: $\mathrm{n}$, number. Bold, p-value lower than 0.05 .

${ }^{a}$ Percentages are based upon available data for each variable.

${ }^{\mathrm{b}} \mathrm{P}$-value calculated from chi-square statistics comparing mothers of survivors to control mothers.

${ }^{\mathrm{c}} \mathrm{P}$-value calculated from chi-square statistics comparing fathers of survivors to control fathers.

${ }^{\mathrm{d}} \mathrm{P}$-value calculated from chi-square statistics comparing households of parents of survivors to households of control parents. 
SUPPLEMENTARY TABLE S2 Socio-demographic determinants of risk-of-poverty ${ }^{\mathrm{a}}$ from univariable logistic regression models (combined dataset including parents of survivors and control parents ${ }^{b}$ )

\begin{tabular}{|c|c|c|c|c|}
\hline & \multicolumn{4}{|c|}{ Parents of survivors $(\mathrm{N}=383)$ and control parents $(\mathrm{N}=769)$} \\
\hline & $\mathrm{OR}^{\mathrm{c}}$ & $95 \% \mathrm{CI}$ & p-value ${ }^{\mathrm{d}}$ & p-value interaction ${ }^{\mathrm{d}, \mathrm{e}}$ \\
\hline Population & & & 0.001 & - \\
\hline Control parents & 1.00 & & & \\
\hline Parents of survivors & 1.65 & $1.22-2.24$ & & \\
\hline \multicolumn{5}{|l|}{ Characteristics of parents } \\
\hline Age at study mother & & & 0.026 & 0.869 \\
\hline$<40$ years & 1.00 & & & \\
\hline $40-45$ years & 0.75 & $0.50-1.11$ & & \\
\hline $45-50$ years & 0.58 & $0.40-0.85$ & & \\
\hline$>50$ years & 0.47 & $0.20-1.09$ & & \\
\hline Age at study father & & & $<\mathbf{0 . 0 0 1}$ & 0.710 \\
\hline$<40$ years & 1.00 & & & \\
\hline $40-45$ years & 0.43 & $0.26-0.70$ & & \\
\hline $45-50$ years & 0.80 & $0.48-1.32$ & & \\
\hline$>50$ years & 0.58 & $0.40-0.84$ & & \\
\hline Migration background mother & & & 0.014 & 0.822 \\
\hline No & 1.00 & & & \\
\hline Yes & 1.51 & $1.09-2.10$ & & \\
\hline Migration background father & & & $<0.001$ & 0.776 \\
\hline No & 1.00 & & & \\
\hline Yes & 2.05 & $1.42-2.94$ & & \\
\hline Education mother & & & $<0.001$ & 0.326 \\
\hline Higher education & 1.00 & & & \\
\hline Standard education & 4.74 & $2.79-8.04$ & & \\
\hline Education father & & & $<0.001$ & 0.345 \\
\hline Higher education & 1.00 & & & \\
\hline Standard education & 9.19 & $5.78-14.61$ & & \\
\hline Employment status mother & & & 0.795 & 0.377 \\
\hline Full-time & 1.00 & & & \\
\hline Part-time/ not employed & 0.93 & $0.54-1.60$ & & \\
\hline Employment status father & & & 0.003 & 1.000 \\
\hline Full-time & 1.00 & & & \\
\hline Part-time/ not employed & 2.01 & $1.27-3.18$ & & \\
\hline Number of children mother & & & 0.705 & 0.165 \\
\hline$\leq 2$ children & 1.00 & & & \\
\hline$>2$ children & 0.94 & $0.69-1.29$ & & \\
\hline Number of children father & & & 0.936 & 0.297 \\
\hline$\leq 2$ children & 1.00 & & & \\
\hline$>2$ children & 1.01 & $0.72-1.43$ & & \\
\hline \multicolumn{5}{|l|}{ Characteristics of households } \\
\hline Language region & & & 0.067 & 0.092 \\
\hline German & 1.00 & & & \\
\hline French/ Italian & 0.73 & $0.53-1.02$ & & \\
\hline
\end{tabular}

Abbreviations: CI, confidence interval; n, number; OR, odds ratio. Bold, p-value lower than 0.05.

${ }^{a}$ Risk-of-poverty was defined as having a monthly household income of $<4500$ Swiss Francs (CHF) for single parents and $<6000 \mathrm{CHF}$ for parent-couples.

'Calculated on weighted analysis (weights on mothers' and fathers' age at study, migration background, education, and the households' language region).

${ }^{c} \mathrm{OR}$ for being at risk-of-poverty. 
${ }^{\mathrm{d}}$ Global p-value calculated from Wald tests.

${ }^{\mathrm{e}} \mathrm{P}$-value for interaction between parents of survivors and control parents. 
SUPPLEMENTARY TABLE S3 Socio-demographic and cancer-related determinants of risk-ofpoverty ${ }^{\mathrm{a}}$ from univariable logistic regression models in parents of survivors

\begin{tabular}{|c|c|c|c|}
\hline & \multicolumn{3}{|c|}{ Parents of survivors $(\mathrm{N}=383)$} \\
\hline & $\mathrm{OR}^{\mathrm{b}}$ & $95 \% \mathrm{CI}$ & p-value ${ }^{c}$ \\
\hline \multicolumn{4}{|l|}{ Characteristics of parents } \\
\hline Age at study mother & & & 0.104 \\
\hline$<40$ years & 1.00 & & \\
\hline $40-45$ years & 0.67 & $0.39-1.18$ & \\
\hline $45-50$ years & 0.56 & $0.33-0.96$ & \\
\hline$>50$ years & n.e. & - & \\
\hline Age at study father & & & 0.007 \\
\hline$<40$ years & 1.00 & & \\
\hline $40-45$ years & 0.32 & $0.15-0.68$ & \\
\hline $45-50$ years & 0.40 & $0.20-0.81$ & \\
\hline$>50$ years & 0.71 & $0.34-1.48$ & \\
\hline Migration background mother & & & 0.063 \\
\hline No & 1.00 & & \\
\hline Yes & 1.56 & $0.98-2.50$ & \\
\hline Migration background father & & & 0.004 \\
\hline No & 1.00 & & \\
\hline Yes & 2.13 & $1.27-3.56$ & \\
\hline Education mother & & & $<0.001$ \\
\hline Higher education & 1.00 & & \\
\hline Standard education & 6.12 & $2.85-13.14$ & \\
\hline Education father & & & $<0.001$ \\
\hline Higher education & 1.00 & & \\
\hline Standard education & 11.51 & $5.82-22.79$ & \\
\hline Employment status mother & & & 0.660 \\
\hline Full-time & 1.00 & & \\
\hline Part-time/ not employed & 1.18 & $0.57-2.46$ & \\
\hline Employment status father & & & $\mathbf{0 . 0 3 7}$ \\
\hline Full-time & 1.00 & & \\
\hline Part-time/ not employed & 2.43 & $1.05-5.62$ & \\
\hline Number of children mother & & & 0.680 \\
\hline$\leq 2$ children & 1.00 & & \\
\hline$>2$ children & 1.10 & $0.71-1.70$ & \\
\hline Number of children father & & & 0.550 \\
\hline$\leq 2$ children & 1.00 & & \\
\hline$>2$ children & 1.15 & $0.72-1.84$ & \\
\hline \multicolumn{4}{|l|}{ Characteristics of households } \\
\hline Language region & & & 0.021 \\
\hline German & 1.00 & & \\
\hline French/Italian & 0.56 & $0.35-0.92$ & \\
\hline \multicolumn{4}{|l|}{ Characteristics of the survivor } \\
\hline Age of survivor at study & & & 0.068 \\
\hline$<9$ years & 1.00 & & \\
\hline $9-12$ years & 1.66 & $0.86-3.23$ & \\
\hline$>12$ years & 0.94 & $0.51-1.72$ & \\
\hline
\end{tabular}

SUPPLEMENTARY TABLE S3 Continued 


\begin{tabular}{|c|c|c|c|}
\hline Age at diagnosis & & & 0.125 \\
\hline$<1$ year & 1.00 & & \\
\hline $1-4$ years & 1.75 & $0.96-3.17$ & \\
\hline$>4$ years & 1.86 & $0.98-3.53$ & \\
\hline Diagnosis (ICCC-3) & & & 0.354 \\
\hline Leukaemia & 1.00 & & \\
\hline Lymphoma & 0.45 & $0.16-1.26$ & \\
\hline CNS tumour & 0.62 & $0.32-1.21$ & \\
\hline Soft tissue sarcoma/ bone tumour & 1.07 & $0.44-2.62$ & \\
\hline Other tumours ${ }^{\mathrm{d}}$ & 0.74 & $0.44-1.23$ & \\
\hline Treatment & & & 0.422 \\
\hline Surgery & 1.00 & & \\
\hline Chemotherapy & 1.72 & $0.89-3.30$ & \\
\hline Radiotherapy & 1.75 & $0.79-3.90$ & \\
\hline Stem cell transplantation & 1.75 & $0.59-5.18$ & \\
\hline Time since diagnosis & & & 0.410 \\
\hline$<8$ years & 1.00 & & \\
\hline $8-11$ years & 0.83 & $0.51-1.36$ & \\
\hline$>11$ years & 0.68 & $0.39-1.21$ & \\
\hline Relapse & & & 0.493 \\
\hline No & 1.00 & & \\
\hline Yes & 1.27 & $0.64-2.55$ & \\
\hline Parent-reported late effects & & & 0.257 \\
\hline No & 1.00 & & \\
\hline Yes & 0.76 & $0.48-1.22$ & \\
\hline
\end{tabular}

Abbreviations: CI, confidence interval; CNS, central nervous system; ICCC-3, International Classification of Childhood Cancer - Third Edition; n.e., not estimated (no variation in outcome); n, number; OR, odds ratio. Bold, p-value lower than 0.05.

${ }^{a}$ Risk-of-poverty was defined as having a monthly household income of $<4500$ Swiss Francs (CHF) for single parents and $<6000 \mathrm{CHF}$ for parent-couples.

${ }^{\mathrm{b}} \mathrm{OR}$ for being at risk-of-poverty.

${ }^{c}$ Global p-value calculated from Wald tests.

${ }^{\mathrm{d} O t h e r}$ tumours included neuroblastoma, retinoblastoma, renal tumour, hepatic tumour, germ cell tumour, Langerhans cell histiocytosis, other malignant epithelial neoplasms, malignant melanomas, and other or unspecified malignant neoplasms. 